\title{
Revitalisatie van het poldermodel
}

\author{
Lei Delsen*
}

Even leek het poldermodel zijn einde nabij. Afgelopen jaar heeft het tweede kabinetBalkenende met grote voortvarendheid getracht om op sociaal-economisch terrein besluiten te nemen en veranderingen door te voeren buiten het poldermodel om. Eenzijdig werden maatregelen afgekondigd zonder de sociale partners daarin te kennen. Deels weken deze voorstellen af van adviezen van de Sociaal-Economische Raad, deels waren zij zelfs in tegenspraak met eerdere gemaakte afspraken met de sociale partners. Hoewel geen verrassing, de inhoud van de voorgestelde ingrepen in de verzorgingsstaat loog er niet om. Conform de regeerakkoorden van Balkenende I en II wordt het moeilijker om in de WW en de WAO te komen. Alleen mensen die vier jaar of langer hebben gewerkt hebben nog recht op een werkloosheidswet (WW-) uitkering. De Wet op de arbeidsongeschiktheidverzekering (WAO) wordt beperkt tot mensen die volledig arbeidsongeschikt zijn. Daarnaast gaat een streep door de fiscale voordelen van VUT- en prepensioensparen. De Nederlandse overheid treedt verder terug. Burgers moeten hun eigen verantwoordelijkheid nemen. De verzorgingsstaat wordt niet alleen afgeslankt, ook de solidariteit wordt ondergraven. Zelfredzaamheid staat voorop. Daarnaast weigerde de minister van Sociale Zaken, De Geus, annvankelijk cao's voor 2005 algemeen verbindend te verklaren (avv) waarin een loonstijging wordt afgesproken. Dit laatste impliceert een kanteling van de Nederlandse arbeidsverhoudingen: een afglijden naar een conflictmodel, waarbij freeriding niet meer mogelijk is en bonden via loonclaims moeten trachten de organisatiegraad op peil te houden. Het avv'en voorkomt concurrentie tussen werkgevers en werknemers binnen een bedrijfstak en draagt daarmee bij aan de stabiliteit van de Nederlandse arbeidsverhoudingen en aan de arbeidsrust.

De eenzijdige maatregelen van het kabinetBalkenende werden gezien als het definitief einde van de Nederlandse overlegeconomie. Het poldermodel kraakte immers al een tijdje in zijn voegen. Al op 9 januari 2002 schreef Wellink, president van De Nederlandsche Bank, in Het Financieele Dagblad het artikel 'Het einde van het poldermodel is nabij'. Dat artikel was de aanzet voor een nieuwe brede discussie over de toekomst van het poldermodel. Een discussie die in de loop van 2002 en 2003 onder invloed van de toenemende sociaal-economische problemen feller en feller is geworden. De kern van de kritiek is het gevaar van stroperigheid: uiteenlopende actoren zijn bij de besluitvorming betrokken waardoor compromissen onvermijdelijk zijn en derhalve echte keuzes vermeden worden.

Tijdens het voorjaaroverleg tussen de overheid en de sociale partners van dinsdag 18 mei 2004 wezen de vakcentrales het voorstel van het kabinet over VUT en prepensioen af. De ruzie tussen de vakbeweging en het kabinet leidde tot acties binnen bedrijven en een grote demonstratie in Amsterdam op 2 oktober. Staken past evenmin als de eenzijdige kabinetsmaatregelen binnen het poldermodel dat is gebaseerd op overleg, solidariteit, gelijkheid en samenwerking van werknemers,

* Lei Delsen is werkzaam bij de Faculteit der Managementwetenschappen van de Radboud Universiteit Nijmegen. E-mail: L.Delsen@fm.ru.nl. 
werkgevers en de overheid bij het aanpakken van sociaal-economische problemen. Nationale culturen zijn zeer stabiel in de tijd. De Nederlandse cultuur kan als een constante worden beschouwd. Toch zijn de stakingen van afgelopen jaar geen smetje op de harmonieuze Nederlandse arbeidsverhoudingen. In tegendeel, zij hebben het poldermodel gerevitaliseerd.

Zonder deze vakbondsacties zou het centraal akkoord van 6 november 2004 niet gesloten zijn. De scherpe kanten zijn van het kabinetsbeleid afgehaald. Op de pijnpunten zijn compromissen gesloten. Het wederzijds vertrouwen is hersteld. Volgens het centraal akkoord kan de VUT- en prepensioenpremie worden gebruikt voor flexibilisering van het pensioen dat vóór de leeftijd van 65 jaar kan ingaan. Daarmee zijn deze premies weer wel fiscaal aftrekbaar voor vervroegd vertrek. Wat de WAO betreft neemt het kabinet grotendeels het eerdere SER-advies over. Doordat de vakbeweging voor 2005 loonmatiging betracht en akkoord gaat met de bevriezing van de ambtenarensalarissen en uitkeringen, is het niet avv'en van tafel gehaald. Uiteraard heeft dat financiële consequenties. Nog voor de bespreking van de begroting voor 2005 had het kabinet al een miljard euro minder bezuinigd. Daar komen dit jaar nog 364 miljoen euro bij als gevolg van het sociale akkoord, oplopend tot 650 miljoen in 2011. Dat akkoord kan bovendien nog een extra tegenvaller opleveren van ruim 500 miljoen euro wanneer de bonden de bezuinigingen op VUT en prepensioen ongedaan kunnen maken via cao-afspraken. Het kabinet vertrouwt erop dat dit slechts in beperkte mate zal gebeuren. De vakbeweging, en daarmee het poldermodel, is na de 300.000 mensen op het Museumplein versterkt uit de onderhandelingskamer gekomen. 